\title{
METAKRITIK UNTUK SUBAGIO SASTROWARDOYO
}

\author{
Arif Bagus Prasetyo \\ International Writing Program, University of IOWA, Amerika Serikat. \\ Email: pasharen@yahoo.com
}

\begin{abstract}
Abstrak
Subagio Sastrowardoyo menghasilkan analisis struktur yang bagus dalam sejumlah kajian sastranya. Salah satunya adalah kajian tentang puisi Sitor Situmorang Sosok Pribadi dalam Sajak. Esai tersebut diajukan Teeuw sebagai contoh dan pembicaraan yang sangat tepat tentang ikhtiar mencari kebulatan makna yang tersembunyi dan sukar dipahami dalam puisi modern. Dalam kasus puisi Situmorang, sorotan atas pemikiran sastra dan budaya Sastrowardoyo ini dilandasi pembacaan terhadap buku Sosok Pribadi dalam Sajak (SPdS), Sastra Hindia Belanda dan Kita, SHBdK dan Bakat Alam dan Intelektualisme. Secara keseluruhan, SPdS ditulis dengan orientasi (yang mengutamakan interpretasi tentang dunia batin, kejiwaan atau sosok pribadi pengarang sebagaimana yang terbayang pada isi karyanya. Penekanan kuat pada isi, disertai kuatnya paham romantik dan modernis yang menempatkan seniman di pusat penciptaan seni, telah mendorong Sastrowardoyo untuk merancukan penilaian mutu karya dan penilaian kualitas pribadi pengarang, mengaburkan perbedaan antara kritik seni dan kritik moralitas, mencampuradukkan persoalan estetika dan perkara etika. Ketajaman, kecermatan dan ketekunan analisis Sastrowardoyo seringkali diredupkan atau dipiuhkan oleh hasrat melakukan semacam "inkuisisi suci" terhadap pengarang. Dalam $S H B d K$, Sastrowardoyo bergeser menjauhi kutub ekspresif dan mendekati kutub struktural, meski tidak pernah kehilangan minat kepada sosok pribadi pengarang.
\end{abstract}

Kata kunci: metakritik, Subagio, SPds, estetika, etika

\begin{abstract}
Subagio Sastrowardoyo produces good structural analysis in a number of literary studies. One is the study of Sitor Situmorang'S poetry Sosok Pribadi dalam Sajak. The essay is submitted by Teeun "as an example and very precise topic" about endeavor of searching the hidden meanings in unanimity and elusive of modern poetry. In Situmorang's poetry, the focus discussion of Sastrowardoyo about literature and culture is based on a reading Sosok Pribadi dalam Sajak (SPdS), Sastra Hindia Belanda dan Kita, SHBdK dan Bakat Alam dan Intelektualisme. Overall, the SPDs are written which prioritizes the interpretation of the inner world, psychiatric or "private figure" author as depicted on the content of his work. Content, strong romantic and modernist understanding that puts the artist at the center of artistic creation, has encouraged Sastrowardoyo to blur quality of assessment and work of the author personally, and to blur the distinction between art criticism and morality criticism, and the issue of aesthetics and ethics matters. Sharpness, accuracy, and diligence analysis are often dimmed by passion on doing "boly inquisition" against the author. In SHBdK, Sastrowardoyo shifts away from expressive to structural approach, though he never lost interest in the "private figure" of the author.
\end{abstract}

Keywords: meta-critic, Subagio, SPDs, aesthetics, ethics

\section{Pendahuluan}

Mendiang Subagio Sastrowardoyo (19241995) adalah salah seorang penyair dan kritikus sastra terpenting dalam sejarah sastra modern Indonesia pasca-kemerdekaan. Selain puisi dan kritik sastra, ia memang juga menulis cerpen dan esai seni/budaya. Cerpen-cerpennya diterbitkan dalam kumpulan Kejantanan di Sumbing (1965, 1982) satu-satunya buku cerpen yang terlahir dari tangannya. Sebelum dibukukan, cerpen "Kedjantanan di Sumbing" mendapat Hadiah Pertama Majalah Kisah tahun 1955. Bukan berarti ia penulis yang kurang produktif. Justru sebaliknya. Sepanjang 71 tahun usia hidupnya, ia menelurkan tujuh buku puisi, dua di antaranya memperoleh penghargaan: Anugerah Seni dari Pemerintah RI tahun 1970 untuk kumpulan Daerah Perbatasan (1970) dan SEA Write Award 1991 untuk kumpulan Simfoni Dua (1990). Puisi "Dan Kematian Makin Akrab" juga memenangi hadiah dari Majalah Sastra Horison tahun 1966/1967. Untuk karya non-fiksi, ia menghasilkan sembilan buku esai (termasuk dalam bahasa Inggris), sekurang-kurangnya dua 
di antaranya berupa kajian sastra, Sosok Pribadi dalam Sajak (1980) dan Sastra Hindia Belanda dan Kita (1983), dengan yang disebut terakhir menyabet Hadiah Sastra DKJ 1983.

Karya non-fiksi Sastrowardoyo dalam bahasa Indonesia tercatat dibukukan dalam enam buku. Selain dua judul yang telah disebut di atas, empat buku lainnya adalah: Bakat Alam dan Intelektualisme (1971), Manusia Terasing di Balik Simbolisme Sitor (1976), Pengarang Modern sebagai Manusia Perbatasan (1989), Sekilas Soal Sastra dan Budaya (1992). Buku Manusia Terasing di Balike Simbolisme Sitor, yang berisi kajian tentang puisi Sitor Situmorang, di kemudian hari digabungkan dengan buku Sosok Pribadi dalam Sajak. Sorotan atas pemikiran sastra dan budaya Sastrowardoyo dalam tulisan ini dilandasi pembacaan terhadap buku Sosok Pribadi dalam Sajak, Sastra Hindia Belanda dan Kita, dan Bakat Alam dan Intelektualisme. Sesuai dengan materi, tulisan ini berfokus pada kritik sastra Sastrowardoyo.

Dalam buku Pengkajian Kritik Sastra Indonesia (2009), Yudiono K.S memasukkan Sosok Pribadi dalam Sajak (selanjutnya ditulis "SPdS") dalam daftar 10 buku kritik sastra yang, menurutnya, "sepantasnya dibaca para mahasiswa", untuk "merangsang dan menggugah semangat mahasiswa untuk menulis kritik sastra yang kelak akan terbaca masyarakat luas". Daftar ini penting, karena Pengkajian Kritik Sastra Indonesia disusun sebagai buku ajar mata kuliah Kritik Sastra Indonesia untuk mahasiswa sastra S-1, dan diterbitkan dengan biaya negara (program Hibah Buku Teks Direktorat Penelitian dan Pengabdian kepada Masyarakat/DP2M Departemen Pendidikan Nasional). Artinya, sepuluh buku kritik sastra tersebut dijadikan sarana memperkenalkan kritik sastra Indonesia kepada mahasiswa sastra — sebagian besar pemangku kepentingan sastra Indonesia pada masa depan. Kita tentu bisa berdebat sampai pagi kenapa sepuluh buku itu yang dipilih, tapi fakta dicantumkannya dan diulasnya buku-buku tersebut dalam buku teks akademis jelas memiliki signifikansi strategis bahkan "politis" tertentu.

\section{Metakritik SPdS dan SHBdK}

SPdS, yang berisi empat kajian puisi, dinilai oleh Yudiono sebagai "contoh kritik sastra Indonesia bergaya populer yang terbilang unggul", dan "dapat diharapkan dari buku tersebut akan terpetik inspirasi penulisan kritik sastra yang bergaya populer yang mutunya terjamin". Menurutnya, signifikansi SPdS terletak pada pandangan Subagio Sastrowardoyo yang menyarankan pentingnya pengalaman estetik atau pengalaman menulis sastra bagi seorang kritikus. Ia mengutip pendapat Rachmat Djoko Pradopo dalam Kritik Sastra Indonesia Modern (2002):

"Orientasi ekspresif Subagio dalam teori dan prakteknya itu dapat diperkirakan berhubungan dengan diri pribadinya sebagai seorang penyair. Bahkan ia mengharapkan (malah mengharuskan) bahwa seorang kritikus sastra itu haruslah juga mempunyai pengalaman menulis sastra meskipun karangan yang ditulisnya itu sedikit atau tidak berhasil (tidak bernilai). Pengalaman itu akan cukup berharga untuk menjadi topangan bagi pandangan kritikus itu mengenai kesusastraan, setidak-tidaknya mengenal proses kejadiannya. Dengan demikian, ia akan mengakui adanya unsur- unsur yang rasional dalam karya sastra, yang subjektif dan bersuasana-misteri”.

Orientasi ekspresif dalam praktek kritik sastra Sastrowardoyo menempatkan karya sastra sebagai cerminan dunia batin pengarang. Sebab, sebagaimana yang dikatakannya dalam "Prakata" SPdS, Sastrowardoyo percaya bahwa "Penyair bersuara dalam sajak. Ia ingin membayangkan dirinya dalam kata-katanya. Ia tidak puas sebelum dirinya terungkapkan dengan sepenuhnya di dalam sajak". Berdasarkan kepercayaan ini, Sastrowardoyo menulis kritik sastra sebagai upaya "untuk membangkitkan pribadi penyair yang terbayang dalam sajak".

Upaya kritis Sastrowardoyo tersebut sesuai dengan ciri pendekatan ekspresif yang merajai kritik sastra di Barat beberapa abad silam, sebagaimana yang diuraikan A. Teeuw dalam Sastra dan Ilmu Sastra (1984): 
"Pada zaman romantik, misalnya, pendekatan terhadap karya sastra yang dominan adalah pendekatan ekspresif: penulis mendapat sorotan yang khas, sebagai pencipta yang kreatif; dan jiwa pencipta itu mendapat minat yang utama dalam penilaian dan pembahasan karya sastra; tidak kebetulan pula pada masa itu puisi lirik dianggap sebagai bentuk sastra yang paling utama. [B]ahwa dalam kritik sastra abad ke-19 pendekatan ekspresif sangat ditonjolkan. Penyair, jiwanya, kreativitasnya, genia- litasnyalah yang menjadi pusat perhatian para pengritik dan ahli sastra, dan karya sastra hanyalah atau terutama menjadi jalan atau sarana untuk memahami jiwa penyair."

Yudiono menutup uraian singkatnya tentang SPdS dengan simpulan "bahwa Subagio Sastrowardoyo menyadari pentingnya pemahaman struktur atau bentuk sajak sebagai sarana pemahaman isinya". Simpulan ini ditarik langsung dari pernyataan Sastrowardoyo dalam SPdS ketika membahas puisi Sitor Situmorang:

"Sesuai dengan hakikat segala sastra, dalam sajak-sajak Sitor, bentuk tidak dapat dipisahkan dari isi. Apa yang tampak sebagai wujud permukaan berupa lambang- lambang adalah sebagian dari sosok kejiwaan juga, boleh dikatakan segi balik dari kehadiran diri yang sama. Sitor dalam menyambutsimbolisme sepertiyang ditemukan di dalam persajakan Prancis dengan tindakan itu sudah melakukan perbuatan melahirkan kejiwaannya. Ia telah mengambil putusan dan memilih yang baginya paling kena menurut selera serta kecenderungan pribadinya".

Pernyataan ini tidak serta-merta menyarankan "bahwa Subagio Sastrowardoyo menyadari pentingnya pemahaman struktur atau bentuk sajak sebagai sarana pemahaman isinya", sebagaimana yang disimpulkan Yudiono. Justru sebaliknya, struktur atau bentuk sajak tampaknya tidak terlalu penting bagi Sastrowardoyo, karena yang lebih dipentingkannya adalah isi, yang dianggap merefleksikan "sosok kejiwaan" pengarang. Tugas kritikus sastra dipahami sebagai menggali "makna orisinal" yang diandaikan sengaja atau tidak sengaja dikuburkan pengarang di bawah permukaan struktur karya sastra. Sebagai kritikus sastra, Sastrowardoyo pada hakikatnya bekerja, dalam istilah Teeuw, "untuk memahami jiwa penyair" - tugas yang lebih cocok dan efektif dilaksanakan oleh psikoanalis dan ahli ilmu jiwa pada umumnya.

Simpulan Yudiono bahwa Sastrowardoyo menyadari pentingnya pemahaman bentuk sebagai sarana pemahaman isi karya sastra lebih tepat dikenakan bukan pada SPdS, melainkan pada buku kajian sastranya yang lain: Sastra Hindia Belanda dan Kita (selanjutnya disebut " $S H B d K$ ”), yang berisi sembilan kajian roman. Dalam $S H B d K$, terutama ketika menganalisis roman Max Havelaar karya Eduard Douwes Dekker dan roman Atheis karya Achdiat K. Mihardja_dua esai terpanjang dalam buku ini-Sastrowardoyo dengan sangat cermat mengupas bentuk cerita berbingkai dan detail perwatakan tokoh cerita, yang digunakan oleh kedua pengarang tersebut untuk "memungkinkan tinjauan kepada realitas secara lain, tidak hanya dari satu sudut seperti di dalam roman-roman yang sedang berlaku, melainkan dari berbagai sudut" (pada Atheis), atau untuk mencerminkan "berganti-ganti sikap dan suara hati pengarangnya dan pasangsurut gelombang batin" yang membangun kekuatan estetis dan daya persuasif karya (pada Max Havelaar). Dalam kasus Atheis, pemakaian struktur cerita berbingkai dipandang Sastrowardoyo sebagai pembaharuan penting dalam sejarah sastra Indonesia:

"Masuknya bentuk cerita berbingkai sebagai jenis karya baru di dalam kesusastraan modern kita mempunyai arti yang penting bagi sejarah sastra. Kurang lebih sama pentingnya dengan masuknya jenis karya- karya lain, seperti bentuk soneta di zaman Pujangga Baru dan sajak bebas di tengah persajakan Angkatan 45, sekalipun sampai kini belum ada peroman lain yang ikut mempergunakan struktur berbingkai itu".

Dalam menelaah Atheis maupun Max Havelaar, di sana-sini Sastrowardoyo masih tampak tergoda untuk mencari-cari kaitan antara 
kenyataan fiksional dalam karya dan kenyataan faktual dalam kehidupan pengarangnya - suatu gejala orientasi ekspresif. Tetapi, terlihat jelas bahwa ia mengutamakan pendekatan structural sehingga hubungan apapun yang ditemukannya antara karya dan "sosok pribadi" pengarang tidak banyak menentukan penilaiannya terhadap karya. Dalam esai "Pendekatan kepada Roman Atheis", Sastrowardoyo menyatakan bahwa tokoh "saya" dalam Atheis "rupanya menyuarakan pendirian pengarangnya di dalam roman masalah ini", namun segera menambahkan bahwa "Kita tidak dapat terlalu pasti tentang hal ini, karena Achdiat dapat saja cuci tangan dan memulangkan pendirian itu kepada juru kisah itu" (walaupun sejurus kemudian Sastrowardoyo kembali tergoda: "Tetapi menilik kesimpulan-kesimpulan yang menyertai peristiwa-peristiwa serta masalahmasalah roman, berat dugaan saya bahwa juru kisah itu bayangan angan-angan pengarangnya sendiri serta mewakili pendiriannya"). Dalam esai "Max Havelaar sebagai Karya Sastra", Sastrowardoyo bahkan seperti menolak orientasi ekspresif:

"Menurut pandangan saya, kalau kita hendak menelaah Max Havelaar sebagai karya sastra, dan tidak sebagai pamflet politik belaka, pengetahuan kita tentang riwayat hidup pengarangnya tidaklah berguna sebagai sarana untuk menguji isi karangan kepada kenyataan sejarah. Tugasnya adalah sebaliknya. Pengetahuan itu untuk meneliti, sampai berapa banyak kenyataan sejarah mengenai kehidupan pengarangnya itu tersaring oleh daya angan-angannya. Penilaian kita lalu didasarkan pada ukuran betapa karya itu meyakinkan serta memperdalam kesadaran batin kita, lepas dari persoalan apakah yang disajikan tepat benaratau tidak dengan kenyataan. Di dalam hal ini pun kita harus ingat, bahwa pemutarbalikan dalam penulisan karya sastra justru bisa menandakan kelembutan serta keliatan daya angan-angan pengarangnya".

Ketika membahas roman dalam $S H B d K$, secara umum dapat dikatakan bahwa-sosok pribadi" pengarang bukan komponen terpenting dari penilaian Sastrowardoyo terhadap karya sastra. Tanggapan Sastrowardoyo terhadap roman Tanah Asalkarya Du Perron dapat disebut sebagai perkecualian. Menurut Sastrowardoyo, roman Tanah Asal-tidak dapat dilepaskan penilaiannya dari penulisnya, karena merupakan penggambaran riwayat hidup dirinya. Menilai roman itu adalah menilai pribadi penulisnya juga". Penilaian kualitas "sosok pribadi" Du Perron merupakan unsur signifikan dari penilaian kualitas roman Tanah Asal:

"Pengejaran kepada gaya Eropah, baik di dalam segi kehidupan umum maupun di dalam segi budaya, tidaklah berlangsung tanpa langkah-langkah yang salah. Semangat yang menyertai usaha itu tidak sedikit menjerumuskan orang kepada sikap sok cendekia yang berlebihlebihan. Du Perron menunjukkan gejala salah langkah demikian".

"Kecendekiaan yang sudah kelewat batas itu telah meninggalkan bekasnya pada gaya menulis Du Perron yang boleh dinamakan abstrak dan mengawang. Du Perron telah menyuguhkan kepada pembaca beranekawarna gagasan dan kejadian-deretan saat-saat di dalam hidupnya yang tak tersaring dan hampir tak ada putus-putusnya-tetapi tidak diberi waktu sedikit pun pada dirinya untuk mengaji setiap peristiwa secara seksama, kecuali secara mengawang dalam perenungan".

"Bagi Du Perron, dunia pengalaman merupakan alam perenungan seorang cendekia. Ia mendekati kenyataan secara abstrak dan umum. Karena tidak sanggup meresapkan diri ke dalam kejiwaan tokoh- tokohnya serta melibatkan diri ke dalam nasibnya, ia pun sudah merasa puas dengan pengamatan permukaan dan deretan saat-saat yang penting dengan yang tak penting, tanpa menegaskan di mana pusat atau tekanan perhatiannya. [...] Kecendekiaan Du Perron belum sanggup menangkap kenyataan pada intipatinya serta memperoleh arah penglihatan kepada titik- titik peristiwa pada garis hidupnya. Pada hemat saya, cita-citanya menjadi cendekia Eropah, seperti yang terkesankan pada roman ini, masih mengandung sikap pura- pura 
dan dibuat-buat".

Dalam penilaian Sastrowardoyo, kelemahan karakter pribadi Du Perron telah menyebabkan roman Tanah Asal menjadi kurang berbobot. Meskipun demikian, bukan berarti roman ini tidak bermutu sebagai sastra. Di mata Sastrowardoyo, kelemahan Tanah Asal terletak pada isi, bukan pada bentuk. Kelemahan karakter pribadi Du Perron yang berdampak negatif pada isi karyanya itu justru berdampak positif pada bentuk karyanya:

"Tetapi bagaimana pun juga, sikap demikian [sikap pribadi Du Perron yang sok cendekia, pura-pura dan dibuatbuat-abp] telah menghasilkan sebuah roman dengan bangun yang unik, yang lain daripada yang lain. [...] Pendekatan kenyataan dari luar yang hanya menyoroti gejala-gejala permukaan terus-menerus dari permulaan sampai akhir menghasilkan metode menulis yang menarik. Dalam hal ini bentuk buku harian roman ini dipergunakan untuk menyarankan benarnya pengalaman yang disaksikan".

Secara umum, $S H B d K$ tidak berorientasi ekspresif, karena faktor-sosok pribadi” pengarang diredupkan oleh sorotan terhadap bentuk atau struktur formal karya sastra, juga hubungan antara karya sastra dan kenyataan sosial-politik-kultural, serta respons pembaca terhadap karya sastra. Situasi kebalikannya terdapat pada SPdS yang usianya lebih tua dari $S H B d K$, dan tidak berisi pembahasan roman, melainkan telaah puisi, lokus aktivitas kreatif Sastrowardoyo sendiri sebagai penyair. Dalam SPdS, orientasi ekspresif mengendalikan penilaian terhadap karya sastra. Pendekatanpendekatan kritis lain, kalau ada, berfungsi menjustifikasi, atau setidaknya menyokong, orientasi ekspresif itu. Struktur atau bentuk atau style puisi, misalnya, dikaji dalam rangka menggali isi atau makna atau pesan puisi, yang diandaikan mencerminkan—sosok kejiwaan" penyair.

Dalam esai "Manusia Terasing di Balik Simbolisme Sitor", Sastrowardoyo secara panjang-lebar membahas bentuk puisi Sitor Situmorang, yang dihubungkannya dengan pantun, soneta, puisi simbolis Perancis sampai haiku Jepang. Pembahasan bentuk puisi Situmorang tersebut memang bermanfaat, dapat menambah wawasan pembaca, namun sesungguhnya tidak esensial, karena hanya berfungsi sebagai semacam pengantar untuk mencari-sosok pribadi" penyair yang diyakini terkristalkan dalam isi puisinya. Sebagaimana yang diakui sendiri oleh Sastrowardoyo, meski sudah bersusah-payah membedah gaya puitik Situmorang, tetap saja muncul pertanyaan:

"Apakah yanghendak dikatakanSitor dengan sajak-sajaknya? Inilah pertanyaan yang melibatkan pikiran saya selama saya membicarakan cara mengungkap Sitor ini. Kita tidak akan sampai pada makna yang hendak ditampilkan Sitor di dalam sajaksajaknya sebelum kita sanggup menembus selaput perlambangannya. Sitor, di dalam sajak-sajak yang terhimpun dalam Surat Kertas Hijau, Dalam Sajak, dan Wajah Tak Bernama sebagian besar mengemukakan diri dalam bentuk simbolik. Kita harus mengenal serta mengerti lebih dahulu langgam bicaranya sebelum kita dapat menangkap pesan yang hendak disampaikan kepada kita, sedangkan langgam bicaranya yang berlambanglambang tidaklah seperti yang telah biasa kita jumpai di dalam persajakan Indonesia. Oleh karena itu, uraian saya sampai kini adalah usaha untuk mencoba memahami wujud perlambangan itu supaya dapat lebih tepat mendekati sosok kejizwaan penyairnya".

Dengan bertanya "Apakah yang hendak dikatakan Sitor dengan sajak-sajaknya?", Sastrowardoyo menganggap puisi sebagai pernyataan, tepatnya pernyataan jiwa penyair. Karya seni, menurut Susan Sontag dalam Against Interpretation (1966), memang dapat dianggap sebagai pernyataan, yakni jawaban atas pertanyaan. Sontag mencatat bahwa setidaknya sejak Diderot, tradisi utama kritik di semua bidang kesenian memperlakukan karya seni sebagai pernyataan yang diungkapkan dalam bentuk karya seni. "Kritikus yang menganggap karya seni sebagai pernyataan",kata Sontag, 
"akan mengkhawatirkan 'gaya'(style)". Dirundung kekhawatiran ini, kritikus bersikap ambivalen terhadap gaya, karena gaya mencerminkan ketegangan antara pernyataan dan cara pernyataan itu disampaikan.

"Sesuai dengan hakikat segala sastra, dalam sajak-sajak Sitor, bentuk tidak dapat dipisahkan dari isi", kata Sastrowardoyo. Pernyataan yang menolak antitesis antara bentuk (atau gaya) dan isi karya sastra, menurut Sontag, lumrah di kalangan kritikus masa kini: "Semua dengan cepat mengamini bahwa gaya dan isi tak terpisahkan, bahwa gaya yang sangat individual pada masing- masing penulis penting adalah aspek organis karyanya dan tidak pernah merupakan sesuatu yang sekadar "dekoratif". Tetapi Sontag mengingatkan bahwa dalam praktek kritik, antitesis kuno tersebut sesungguhnya tetap bertahan. "Pada kenyataannya," ujar Sontag, "amat-sangat sulit berbicara tentang gaya sebuah novel atau puisi tertentu sebagai 'gaya' semata, tanpa menyiratkan, entah sengaja atau tidak, bahwa gaya sekadar dekoratif, aksesoris".

Sinyalemen Sontag ini cukup mengena pada kasus Sastrowardoyo. Ketika membedah gaya puisi Situmorang, Sastrowardoyo berkomentar:

"Dalam menyambut soneta dan sajak-sajak yang serupa sebagai bentuk pengucapan, Sitor juga tidak dapat lepas dari kecenderungan seperti yang tampak pada Baudelaire, yakni keinginan hendak terlalu banyak berceloteh. Karena hendak memenuhi syarat-syarat panjang baris, rumus sajak, serta variasi bentuk lambang, tak urung Sitor lantas bermain-main dengan kata di dalam kesempatan yang diberikan oleh bentuk sajak. Ada semacam woordcultuur, peradaban kata-kata yang dipupuk oleh cintanya hendak berbicara secara indah. Hal ini telah menjadi ciri yang negatif pada sajak-sajak Pujangga Baru karena mengikuti kebiasaan pada Gerakan Sastra 80 di Negeri Belanda dan kini melengket lagi pada sajak-sajak Sitor. Di dalam soneta dan sejenisnya ini terdapat terlalu banyak ruang dan waktu yang tersedia bagi penyair antara pengalaman batin yang dirasakan dengan cara-cara menyatakan diri dengan molek dan teratur".

Sastrowardoyo menyambut gaya berpuisi Situmorang, membahasnya dengan sangat antusias, tapiserentak denganitumenganggapnya sebagai sesuatu yang semu dan kenes belaka, -cara-cara menyatakan diri dengan molek". Tendensi menganggap gaya puitik personal sebagai sekadar aksesori dekoratif juga tersirat dalam kritik Sastrowardoyo tentang kumpulan Ballada Orang-Orang Tercinta Rendra.

$$
\text { Interpretasi yang diamalkan }
$$

Sastrowardoyo dalam SPdS bertujuan menggali isi karya yang dibayangkan sebagai pernyataan jiwa pengarang. Interpretasi semacam ini, di mata Sontag, mengindikasikan ketidakpuasan yang disengaja atau tidak disengaja terhadap karya, keinginan untuk menggantikan karya dengan sesuatu yang lain di luar karya itu sendiri. Sontag mengecam praktek penafsiran demikian sebagai "menganiaya seni": "mengubah seni menjadi barang untuk dipakai, menyusunnya jadi skema kategori-kategori mental". Sebagai gantinya, ia mendorong kritikus agar lebih memperhatikan bentuk karya. Penekanan berlebihan pada isi karya dipandangnya mengundang arogansi penafsiran. Karena itu, yang dibutuhkan adalah kosa bentuk, yakni deskripsi bentuk. "Kritik terbaik, dan ini langka, adalah jenis kritik yang melarutkan pertimbangan isi ke dalam pertimbangan bentuk", kata Sontag. Ia menyebut, antara lain, buku On Racine karya Roland Barthes sebagai contoh "kritik terbaik".

Menitikberatkan pada bentuk dan mengangkat Roland Barthes sebagai tauladan, Sontag dapat dipandang sebagai pendukung kaum kritikus strukturalis/pascastrukturalis. Memakai kacamata strukturalis/pascastrukturalis Sontag untuk menilai SPdS jelas tidak adil, karena Sastrowardoyo secara eksplisit menyatakan bahwa kajian-kajiannya dalam buku ini berorientasi ekspresif untuk mencari "sosok pribadi" penyair. Pendekatan kritis Sastrowardoyo ini sama sekali tidak menjadi persoalan. Hal ini karena, kritik sastra 
yang unggul dan memikat bisa muncul dari pendekatan apa pun.

Kalau dalam tulisan ini mendengungkan Sontag, itu lebih karena kritiknya terhadap golongan kritikus yang menganggap seni sebagai pernyataan, dan karena itu mengidap kekhawatiran atau ambivalensi terhadap gaya, mengena pada praktek kajian sastra Sastrowardoyo dalam SPdS. Menurut Sontag, ambivalensi terhadap gaya berakar pada hasrat ingin melindungi dan mempertahankan nilainilai yang secara tradisional dipahami sebagai berada diluar seni, yakni kebenaran dan moralitas. Yang bersemayam di balik ambivalensi terhadap gaya adalah kerancuan hubungan antara seni dan moralitas, antara estetika dan etika. Itulah tepatnya yang mengganggu pada SPdS: bahwa Sastrowardoyo menafsirkan puisi bukan saja untuk menerawang dunia batin penyair, tetapi juga untuk "mengadili", atau sekurangkurangnya mempertanyakan, moralitas pribadi penyair. Terutama dalam esai "Kerancuan Pribadi Rendra-Lorca", terasa betul bahwa pertanyaan perihal moralitas pribadi Rendra adalah alasan penting, kalau bukan terpenting, dari ditulisnya kajian kritis Sastrowardoyo tentang kumpulan puisi Ballada Orang-Orang Tercinta. Dengan kadar berbeda-beda, semua esai dalam SPdS merancukan penilaian tentang karya sastra dan penilaian tentang moralitas pengarang.

Niat mengkritik moralitas pengarang sudah terasa sejak paragraf-paragraf awal SPdS. "Ini bukan kecaman terhadap Chairil Anwar. Kurang ada keberanian pada saya untuk mengutik-utik kedudukan tokoh sastra kenamaan itu", tulis Sastrowardoyo dalam paragraf pertama esai “Orientasi Budaya Chairil Anwar". Sasaran tembak Sastrowardoyo jelas Chairil Anwar sebagai pribadi, seorang "tokoh sastra kenamaan". Bahwa yang dibidik adalah pribadi Chairil Anwar dan bukan puisinya, lebih eksplisit terbaca pada pernyataan Sastrowardoyo selang beberapa paragraf kemudian: "Dukungan yang begitu luas kepada Chairil sebagai penyair yang terkemuka di dalam sastra Indonesia bisa mengecutkan hati yang hendak menelaab penyair dengan karya-karyanya dari asas dan penglihatan yang lain" [cetak miring oleh saya]. Apakah "menelaah penyair" bukan sekadar kesilapan redaksional, padahal maksudnya "menelaah puisi"? Mungkin saja. Yang jelas, Sastrowardoyo menyejajarkan "kekeramatan kedudukan" atau "kultus individu" Chairil Anwar dengan sejumlah tokoh seniman kondang lain, tapi terutama dengan Rendra. Tulis Sastrowardoyo:

"Di zaman kita sekarang, pemujaan tanpa kritik itu berlaku pula terhadap Rendra. Apapun yang dinyatakannya, dalam bentuk sajak atau pun dalam bentuk teater, dipandang umum menakjubkan dan rupanya telah hilang kepekaan terhadap unsur-unsur sensasi dan pencarian popularitas yang melemahkan sajak-sajaknya".

Dengan mengatakan bahwa "unsur-unsur sensasi dan pencarian popularitas" melemahkan sajak-sajak Rendra, Sastrowardoyo menunjuk kelemahan moralitas pengarang sebagai sumber kelemahan karya. Ketika diungkapkan dalam konteks penyejajaran dengan Chairil Anwar, kasus kelemahan moralitas Rendra itu mengisyaratkan kritik terhadap moralitas Chairil Anwar-meski yang dimaksud dalam esai Sastrowardoyo bukan moralitas dalam pengertian perilaku bohemian dan gaya hidup "jalang" Chairil Anwar yang melegenda itu. Bukan kebetulan belaka bahwa dalam esai tersebut, Sastrowardoyo menyinggung kasus tuduhan plagiat terhadap Chairil Anwar, yang konon menulis puisi "Krawang-Bekasi" dengan mencontek puisi "The Young Dead Soldiers" Archibald Macleish—sebuah kasus pelanggaran moral.

Dalam esai "Orientasi Budaya Chairil Anwar", Sastrowardoyo mengkritik moralitas Chairil Anwar yang dinilainya sebagai penyair yang tidak berpijak di bumi sendiri, seorang sastrawan pribumi yang terkultuskan menjadi simbol nasional dan nasionalisme Indonesia, tetapi ironisnya justru berselera budaya asing (Eropa). Dengan menafsir sekitar 20 puisi Anwar, atau kira-kira 30\% saja dari total puisi 
penyair ini, Sastrowardoyo sudah sanggup menilai kepribadian Chairil Anwar! Sang kritikus sampai pada simpulan bahwa "Chairil tidak setia kepada ke-indo-an budaya manusia Indonesia modern, yang mendapatkan ilham kelahirannya dari dua pusat kerinduan, yang masing-masing mempunyai gairah". Padahal, lanjut Sastrowardoyo (dan inilah inti kritiknya terhadap moralitas borjuis-Eropa Chairil Anwar):

"Di dalam upaya menuju modern, artinya berjalan setingkat dan setapak dengan zaman yang sedang berkembang, kita senantiasa harus berbudaya Indo, tanpa mempunyai darah Indo sendiri, seperti waktu kita dirikan kebudayaan Indonesia-Hindu dan Indonesia- Islam. Jiwa kita tetap berakar di bumi Indonesia sambil meresapkan garis-garis pribadi baru yang diguratkan zaman. Chairil dengan sengaja telah mencabut akar kejiwaan itu dan menyangka diri berjïwa Eropa yang dikenalnya dalam abstraksi".

Kesimpulan yang menotalkan ini mencengangkan, karena didasarkan pada interpretasi atas sebagian khazanah puisi Chairil Anwar-ya, sebagian kecil saja. Dan sebagian kecil puisi itu pun lebih sering dibahas fragmen-fragmennya saja. Sastrowardoyo terkesan menyeleksi fragmen- fragmen puisi Anwar yang mendukung tesisnya bahwa penyair terbesar kita itu "menyangka diri berjiwa Eropa". Tidak tertutup kemungkinan bahwa Sastrowardoyo sejak awal sudah berprasangka bahwa jiwa Anwar keeropa-eropaan, kemudian baru memilih fragmen-fragmen puisi tertentu untuk membuktikan prasangka itu.

Salah satu metode Sastrowardoyo untuk membuktikan keeropaan jiwa Chairil Anwar adalah dengan mengisolasi sejumlah "gatra puisi" yang dinilai "terlalu jauh dari lingkungan pengertian budaya yang biasa pada kita di Indonesia". Gatra "mengembara serupa Ahasveros" dalam puisi "Tak Sepadan", gatra "Thermopylae" dalam puisi "Malam", dan gatra "Itu tubuh / mengucur darah / mengucur darab / rubub / patah / mendampar tanya: aku salah?' dalam puisi
"Isa" dianggap membuktikan betapa "Chairil mendasarkan pemakaian gatranya pada pola berpikir yang sudah tersedia di Barat, tetapi yang tidak terangkum di dalam alam cita dan pikiran Indonesia", dan itu berarti "Chairil telah memilih masyarakat Budaya Eropa sebagai publik pembacanya". Cukup dengan mengajukan petikan tiga puisi itu, Sastrowardoyo berani menarik kesimpulan bahwa "Ia [Chairil Anwar] tidak setia kepada dunia angan-angan masyarakat sekelilingnya, sedangkan ia masih berhutang bahasa yang dipergunakannya". Mencengangkan, sama sekali tidak terlintas dalam benak Sastrowardoyo bahwa Chairil Anwar juga menulis puisi dengan gatra yang dapat dipandang "setia kepada dunia anganangan masyarakat sekelilingnya". Misalnya, puisi "Diponegoro" dan "Persetujuan dengan Bung Karno" yang membayangkan gelora semangat perjuangan bangsa Indonesia, puisi "Di Masjid" dan "Doa" yang memantulkan visi religius beraroma mistik Islam, gatra "Beta Pattiradjawane" dan gaya atavisme mantra dalam puisi "Cerita Buat Dien Tamaela", ungkapan "Masyumi + Muhammadiyah" dalam puisi "Sorga" dsb.

Rupanya, tidak terpikir oleh Sastrowardoyo bahwa kritikus yang sama juga bisa menghubungkan puisi berjudul "L'education Sentimentale", "salam kepada Heidegger" dan "Jenderal Lu Shun" karya penyair bernama Subagio Sastrowardoyo dengan budaya negeri asing, dan berkesimpulan bahwa si penyair "tidak setia kepada dunia angan-angan masyarakat sekelilingnya”. Anggaplah Chairil Anwar menulis puisi dengan membayangkan "masyarakat Budaya Eropa sebagai publik pembacanya", tepatnya pembaca Indonesia yang "terdidik di dalam lingkungan budaya dan sastra Barat". Kalau begitu, apa bedanya dengan Subagio Sastrowardoyo ketika menulis SPdS yang sarat rujukan Barat, atau mengarang sejumlah puisi yang menyinggung filsafat, sejarah, budaya dan situasi mancanegara? Dalam hal ini, Chairil Anwar memakai perbendaharaan Barat sambil membayangkan publik pembaca yang sejenis dengan pembaca karangan-karangan 
Sastrowardoyo sendiri, yakni kaum cerdikcendekia pribumi, yang sejak zaman Pujangga Baru sudah biasa mengunyah pemikiran Barat. Rasanya terlalu berlebihan kalau ia dijatuhi vonis moral "dengan sengaja telah mencabut akar kejiwaan itu dan menyangka diri berjiwa Eropa".

Dengan mengatakan bahwa Chairil Anwar "dengan sengaja telah mencabut akar kejiwaan itu dan menyangka diri berjiwa Eropa" serta "tidak setia kepada dunia angan- angan masyarakat sekelilingnya", Sastrowardoyo praktis menempatkan Chairil Anwar di barisan seniman modern Indonesia yang karyanya dianggap tidak mencerminkan kepribadian bangsa. Padahal, dalam esai "Adakah Perkembangan Seni Modern Wadjar" (Bakat Alam dan Intelektualisme) yang ditulis pada akhir 1950-an, Sastrowardoyo tegas mengatakan "...[K]ita tidaklah amat adil dan benar kalau kita menjangka bahwa seniman modern dari berbagai usia dan angkatan hanja tersesat pandangannja dan tidak sadar akan kepribadian bangsa sendiri...". Disadari atau tidak, selang dua puluh tahunan setelah menulis esai itu, sikap Sastrowardoyo berbalik $180^{\circ}$, sehingga merasa "amat adil dan benar" ketika mengkritik seniman modern bernama Chairil Anwar berdasarkan teori "kepribadian bangsa".

Dalam esai "Adakah Perkembangan Seni Modern Wadjar", menanggapi antitesis antara seni modern dan seni lama dalam konteks kedudukannya di tengah masyarakat Indonesia, Sastrowardoyo menganut paham anti-esensialis yang melihat "kepribadian bangsa" secara dinamis:

"Memang kita harus menilai dan mempertimbangkan kewadjaran seni dari sudut kepribadian bangsa sendiri, tetapi kepribadian itu harus kita bajangkan sebagai struktur tjita2 jang bersifat dinamis, jang selalu berubah. Struktur tjita2 itu mempunjai pola jang tetap, tetapi pola itu mengalami kedjiwaan dan tanggapan jang berbeda-beda dan berubahubah melalui perkembangan zaman".

Sastrowardoyo juga menolak "penglihatan statis" yang memandang dunia Barat dan dunia
Timur sebagai "kesatuan2 peradaban jang bersifat homogeen dan tertutup rapat2 batas pemisahannja", "dua kesatuan peradaban jang berbeda dan terpisah dengan mutlak". Kompleks pandangan esensialis tentang kepribadian bangsa, dunia Barat dan dunia Timur inilah yang menurut Sastrowardoyo telah menimbulkan pertanyaan-pertanyaan yang menyangsikan kedudukan dan kewajaran seni(man) modern di tengah masyarakat Indonesia, seperti:

"Kalau kita membuat sadjak dengan bentuk dan semangat jang meneruskan persadjakan dunia Barat, adakah kita mengusahakan kesusasteraan Indonesia?"

"Mengapakah berpuluh dan beratus seniman kita dewasa ini dapat melaksanakan seni, jang dinamakan modern, dengan wadjar saja seakan-akan tidak ada tjara lain jang mereka kenal daripada jang mereka dapat dari dunia seni Barat? Adakah hal itu disebabkan karena mereka kurang menginsjafi kepribadian bangsa sendiri atau mereka kurang djudjur terhadap kenjataan djiwa sendiri dengan meniru-niru tjorak serta pernilaian seni Barat?"

Bagi sang penulis Bakat Alam dan Intelektualisme, pertanyaan-pertanyaan seperti itu anakronistis. Ia yakin eksistensi seni(man) modern Indonesia yang berorientasi Barat adalah sepenuhnya wajar, tidak boleh dikecam sebagai "kurang menginsyafi kepribadian bangsa sendiri" atau "kurang jujur terhadap kenyataan jiwa sendiri”, karena mencerminkan semangat zaman dan besarnya pengaruh kebudayaan Barat pada situasi aktual kehidupan masyarakat. Dalam esai "Unsur-Unsur Tidak Sadar Di Balik Teater Rendra", sang kritikus juga menyambut positif pertunjukan teater "Bip-Bop" Rendra yang diasosiasikannya dengan gerakan sastra, teater dan seni rupa modern Barat. Sebaliknya, bagi sang penulis SPdS di kelak kemudian hari, seni(man) modern Indonesia yang kebaratbaratan justru patut dikritik dari segi moralitas sebagai tercerabut dari jiwa/kepribadian bangsa sendiri (Chairil Anwar), atau sebagai lagak sok belaka (Sitor Situmorang). 
Dalam esai "Manusia Terasing di Balik Simbolisme Sitor", Sastrowardoyo berulang kali menisbahkan kekuatan puisi Sitor Situmorang pada krisis batin sang penyair. Berikut kutip sebagian di antaranya:

diri "Kesadaran akan kegagalan berkomunikasi dari dunianya yang asing itu justru memberi suasana estetik yang menarik pada karya- karyanya. Setiap sajak yang keluar dari tangannya adalah buah dari pergulatannya dengan nasib [...]

"Pengembaraan Sitor tidak boleh dipandang sebagai kecenderungan individual dan romantis, yang terdorong oleh ketidakpuasan dengan kenyataankenyataan yang terjadi pada tempat ini dan saat ini lalu hendak mencapai ruang dan waktu yang jauh, yang tampaknya lebih menyenangkan. Alasan pengembaraan Sitor bukanlah ketidakpuasan itu, melainkan kegagalannya dalam mempertalikan diri dengan dunia luar. Tanggapannya mengenai gapaian rindu tersia-sia yang menimbulkan keresahan serta petualangannya dari kekosongan ke kekosongan adalah tanggapan nasib kemanusiaan yang universal, yang melibatkannya di tengahnya. Sitor telah melihat esensi kemanusiaan dengan bercermin pada nasib sendiri. Dengan mengalihkan perhatiannya dari masalah cinta asmara ke perkawinannya, ia telah meningkatkan lirik keakuan pada lirik kekitaan, perkembangan persajakan yang membawa kerja sastranya pada tahap filosofis".

\footnotetext{
"Yang menyebabkan sajak-sajak Sitor menarik di dalam penelaahan adalah dramatik kejiwaan yang kita lihat menapasinya, tetapi yang pada waktu sekali baca tidak tampak. Di balik permukaan yang hampir cermat, tenang, dan bersih rupanya ada lubuk yang resah dan meronta-ronta. Dibanding dengan sajak Chairil Anwar, sajak-sajak Sitor itu berkesan lebih diam dan menahan diri sekalipun pergulatan batin yang dialaminya tidak kalah tegang".
}

\begin{abstract}
"Perjuangan batin yang terjadi di dalam diri Sitor tidak saja bersifat perseorangan dan kebudayaan, tetapi juga bersifat kerohanian. Ia menggapai kekasih di seberang lautan, menggapai tanah air di mana ia sudah merasa terkucil, dan menggapai Tuhan yang tidak lagi memberi keyakinan yang penuh. Setiap kali ia merasa terasing bila menyadari kegagalannya hendak menambatkan diri”.

"Kemelut yang rupanya dialami Sitor tersamar di balik wajah tenang sajaksajaknya. Kemelut itu terjadi dalam alam kejiwaan Sitor, yang ingin membukakan diri dan lepas dari keterasingan diri. Nada kebingungan yang terkekang selalu menyertai keinsyafannya akan kegagalannya hendak mencapai pertalian diri yang sepenuhnya dengan dunia luar".

"Inilah tragedi batin yang
terkandung dalam sajak-sajak Sitor.
Kesepian yang timbul dari keterasingan
diri itu mendatangkan kedukaan dan
kenanaran. Akan tetapi, keterasingan
itu justru membuahkan karya- karya
sajaknya karena kesadaran diri terasing
itu mendorong Sitor menggapai ke
luar sekalipun terasa sia-sia. Keinginan
mengungkap diri dalam sajak adalah usaha
untuk mengatasi keterasingan itu".
\end{abstract}

Pernyataan semacam ini bertebaran di sekujur esai Sastrowardoyo tentang puisi Situmorang. Terlihat jelas bahwa Sastrowardoyo meyakini adanya pergulatan batin atau kemelut kejiwaan pada diri Situmorang. Sebagai konsekuensi dari paham romantik yang mendasari kritik sastranya bahwa puisi adalah pernyataan jiwa penyair, Sastrowardoyo memang harus meyakini itu. Dapat dikatakan bahwa tesis "manusia terasing di balik simbolisme Sitor" sepenuhnya bersandar pada keyakinan tentang adanya sosok "manusia terasing"-yakni pribadi yang mengalami krisis batin hebat akibat didera keterasingan diri-bernama Sitor Situmorang, yang menulis puisi untuk mengungkapkan keterasingannya itu. Dalam kerangka orientasi ekspresif Sastrowardoyo, keyakinan ini bukan saja sah, tetapi wajib hukumnya.

Masalahnya, setelah menghubungkan keterasingan Situmorang yang menimbulkan 
krisis batin hebat itu dengan filsafat eksistensialisme, Sastrowardoyo justru menyangsikan, bahkan cenderung tidak percaya, bahwa sang penyair betul-betul mengalami tragedi batin sebagaimana yang terbayang pada puisi-puisinya:

"Mungkinkah pandangan dan sikap Sitor yang berwatak eksistensialisme itu hanya pose belaka, hanya tampang kefilsafatan yang dibuat-buat saja? Benarkah keterasingan diri dan tragedi batin itu sungguh-sungguh dialami oleh Sitor atau adakah semua itu hanya anganangan filsafat yang bermain di dalam benak penyairnya saja? Pertanyaanpertanyaan ini bisa timbul pada kita, kalau kita menginsafi bagaimana mungkin kegelisahan dan keresahan jiwa itu dapat diacu dan disalut di dalam bentuk cermat dan teratur seperti sajak-sajak bergaya soneta, pantun, dan syair. Bagaimana keresahan batin yang melejat- lejat itu disalurkan dalam bentuk ucapan yang tertib dan mengekang itulah yang menjadi soal di sini. Adakah pengalaman batin itu hanya pose belaka atau permukaan bentuk ucapan sajak itu yang merupakan gaya yang pura-pura, yang menyembunyikan tenaga batin yang sebenarnya?

Betul-betulkah dialami kesadaran filsafat eksistensialisme itu oleh Sitor, dengan keterasingan dirinya, kesepiannya, keterlontarannya di dunia, nihilismenya, putusnya hubungan dengan Tuhan, pengembaraannya mencari nilai, dan kedukaannya, atau sekadar hanya hendak mengikuti aliran pikiran modern yang berpengaruh pada zamannya? Dengan kata- kata lain, adakah krisis batin yang terbayang dari sajak-sajaknya sungguhsungguh dialami Sitor, krisis yang harus dilalui dalam menyadari akan sia-sianya usaha untuk mempertalikan diri dengan dunia di luar dirinya?"

Kekhawatiran dan/atau ambivalensi terhadap "bentuk ucapan yang tertib dan mengekang", yang dipandang bertentangan dengan isi puisi yang menyuarakan "keresahan batin yang melejat-lejat", telah mendorong
Sastrowardoyo untuk menjatuhkan vonis moral kepada Situmorang sebagai penyair yang, kurang-lebih, munafik. Hal ini dapat dikatakan "vonis", karena berondongan pertanyaan di atas sebetulnya retoris saja, dan sudah jelas jawabannya bagi Sastrowardoyo. Kita baca komentarnya tentang Situmorang dalam esai "Hati Sabar Toto Sudarto Bachtiar": "Tentang Sitor Situmorang, kita dapat mengatakan bahwa gagasan serta sikapnya, yang sering terasa sebagai pose belaka, sikap yang dibuat-buat, berpangkal pada filsafat eksistensialisme".

Vonis serupa juga kita baca dalam esai "Kecendekiaan Du Perron dalam Roman Tanah Asal" (SHBdK), meski mungkin menyangkut karangan di luar puisi:

"Di dalam hal ini saya teringat akan segi lain di dalam karangankarangan Angkatan 45, yakni gaya upayanya, khususnya yang ditulis oleh Sitor Situmorang, Iwan Simatupang dan Wiratmo Sukito. Upaya- upayanya mengenai sastra, budaya atau politik yang berkesan kabur-kabur dengan sejumput kesombongan serba tahu adalah hasil dari pendekatan persoalan secara umum dan abstrak. Bukankah ini pengikut gaya cendekia Du Perron dan bukankah dengan demikian pengarang-pengarang Angkatan 45 itu juga sekedar - bermain bola dengan tanggapan-tanggapan umum" saja seperti Du Perron?”

Baiklah kita ingat kembali bahwa di mata Sastrowardoyo, Du Perron adalah pengarang yang menulis dengan gaya "sok cendekia yang berlebih-lebihan" serta "sikap pura-pura dan dibuat-buat".

Mencengangkan bahwa Sastrowardoyo seperti meremehkan goyahnya atau bahkan hilangnya keyakinannya terhadap kebenaran krisis batin Situmorang. Seperti tanpa beban, ia menulis:

"Pertanyaan-pertanyaan yang muncul dan masih menggantung pada pembicaraan sajak Sitor ini sebenarnya bertalian dengan masalah kritik mengenai hal kesungguhan pengalaman, hal sincerity, di dalam karya sastra. Di dalam 
kritik sastra, masalah tentang apakah kesungguhan pengalaman di balik penciptaan merupakan unsur yang tidak boleh atau sebaliknya harus terpisahkan dalam pertimbangan sastra, masih menjadi perbincangan yang belum habis. Akan tetapi, tidak dapat saya sangkal kenyataan, dalam membahas sajak-sajak Sitor ini, pertanyaan-pertanyaan mengenai sincerity Sitor ini selalu timbul dalam benak saya".

Sesungguhnya, memang hanya Tuhan dan Situmorang sendiri yang tahu apakah ia benar- benar mengalami krisis batin. Tetapi, dalam konteks esai "Manusia Terasing di Balik Simbolisme Sitor", Sastrowardoyo tidak dapat meragukan atau menyangkal krisis batin Sitomurang yang melandasi interpretasinya dalam esai tersebut. Sekurang-kurangnya, sang kritikus harus tetap berasumsi bahwa Situmorang memang benar mengalami krisis batin, sebab jika asumsi ini dibatalkan, maka bangunan tesis "manusia terasing di balik simbolisme Sitor" nan canggih dan anggun itu akan runtuh.

Konsekuensi logis ini jelas tidak disadari oleh Sastrowardoyo. Dengan mantap ia mengatakan: "Lepas dari soal kesungguhan kesadaran filsafat eksistensialismenya dan ada tidaknya krisis batin dalam dirinya, karya sajaksajak Sitor sendiri memberi persaksian akan hasil pengungkapan sastra yang pelik dan menarik". Secara umum, saya sepakat bahwa puisi Situmorang memang bermutu. Tapi secara khusus, dalam kerangka tesis Sastrowardoyo tentang "manusia terasing di balik simbolisme Sitor", adanya krisis batin sang penyair dan kesadaran filsafat eksistensialismenya itulah yang menentukan mutu, kekuatan dan keunggulan puisi Situmorang. Dengan menyangsikan kesungguhan pengalaman krisis batin Situmorang, Sastrowardoyo seperti mengisyaratkan bahwa krisis batin tersebut hanya terjadi di dalam teks, sebatas terbayang pada puisi di mata sang penafsir. Tetapi kalau demikian, ketika melihat kontradiksiantara isidan bentuk puisi, ketidakcocokan antara "keresahan dan ketegangan batin" dan "cara bersajak yang tenang, terpikir, terpelihara, dan hampir berkesan serba resmi", ketidakharmonisan antara "kenanaran dan kegelisahan" dan "tampang yang cermat dan tertib", mestinya sang kritikus mempertanyakan seni Situmorang - bukan mempersoalkan moralitas Situmorang, memperkarakan kesungguhan atau kepurapuraan sang penyair. Di sinilah Sastrowardoyo merancukan penilaian estetika dan penilaian etika.

Esai "Kerancuan Pribadi Rendra-Lorca" bahkan nyaris bukan lagi kritik seni, melainkan kritik moralitas terhadap Rendra, khususnya selaku pengarang Ballada Orang-Orang Tercinta. Dalam esai ini, penilaian etika jauh lebih dominan daripada penilaian estetika. Tanpa tedeng aling-aling, Sastrowardoyo menuding Rendra munafik, sejak permulaan esai ini:

"Kalau ada sastrawan yang cenderung silap untuk membedakan sungguh-sungguh dengan pura-pura, itu adalah Rendra.[...] Akibatnya, kita melihat pada balada- baladanya yang terkumpul di dalam Ballada Orang-Orang Tercinta yang mengandung kerancuan pribadi RendraLorca. [...] Dalam membaca baladabalada Rendra, orang akan repot menerka siapa yang berbicara, Rendra atau Lorca”.

Setelah dirasa cukup membuktikan kemunafikan Rendra dalam menulis Ballada Orang-Orang Tercinta, Sastrowardoyo menutup makalahnya dengan simpulan yang menyiratkan bahwa Rendra, lebih dari seorang munafikin, adalah sejenis penipu - persisnya penipu yang gagal memperdaya sang kritikus:

"Bagaimanapun juga, yang sudah terang bagi saya ialah bahwa setidaktidaknya di dalam Ballada Orang-Orang Tercinta Rendra terlalu banyak berpulas dan berjingkrak- jingkrak di atas Pentas Sastra, di hadapan publik yang sangkanya terlalu dungu untuk bisa membedakan antara permukaan dan gerak-gerik yang bersungguh-sungguh dan yang berpurapura”.

Dalam menyelenggarakan kritik moralitas terhadap Rendra, Sastrowardoyo pertama- 
tama menyarankan bahwa bentuk atau gaya puisi Rendra hanyalah aksesori dekoratif untuk mewadahi isi yang tidak berbobot. Balada Rendra ibarat baju yang meriah dan menor bagi tema yang dangkal dan kekanak- kanakan:

"[S]ajak-sajak Rendra di dalam kumpulannya yang pertama ini berkesan sebagai penggambaran alam khayal yang meliputi pikiran pemuda yang baru meningkat dewasa. Pokok perhatiannya menyangkut soal-soal remeh, tetapi yang masih dirasa gawat oleh orang yang berumur sekitar dua puluh tahun [...]

Balada-balada Rendra memang tidak memberi kesempatan kepada pembaca untuk berhenti berpikir dan merenung di dalam saatsaat hening. Yang penting ditangkap adalah kesan-kesan permukaan dari adegan- adegan menggemparkan di dalam peristiwa perkosaan perempuan, adu otot, pembunuhan keji, dan pamer kejantanan. Melodrama dengan penekanan pada perbuatan-perbuatan lahir serta pencarian efek emosi yang dilebih-lebihkan di dalam sajak-sajak ini pada pembacaan pertama tidaklah terasa karena pembaca cenderung terhanyut dalam retorik yang ramai gemuruh dan terpesona oleh kemanisan citra (imagery) sajak.

Kalau kita sangkutkan dengan permainan wayang, balada-balada Rendra baru sampai pada pertikaian yang ramai antara tokoh-tokoh kesatria yang bertanding dan belum mencapai tingkat perenungan hidup yang disarankan ki dalang".

Pada tahap ini, kritik Sastrowardoyo terhadap Rendra terdengar mirip kritiknya terhadap Du Perron. Seperti Du Perron yang moralitas sok cendekianya menghasilkan bentuk roman yang menarik, moralitas kekanakkanakan Rendra membuahkan gaya pengucapan yang memikat:

"Dramatik kejadian yang berlaku di permukaan hidup di dalam baladabaladanya merupakan segi kekuatan Rendra karena dengan selera serta bakat itu penyair ini telah berhasil menaikkan kemampuannya mengarang setinggi mungkin. Cerita kejadian lahir yang sederhana tanpa mengandung penglihatan hidup yang dalam sudah cukup memberi nilai pada jenis karya balada ini. Kedataran peristiwa di dalam kisah balada Rendra tersebut mendapat imbangan yang mengesankan dari pemakaian citra sajak yang belum pernah dijumpai di dalam kesusastraan Indonesia".

Pada tahap kedua, yang merupakan inti tesis "kerancuan pribadi Rendra-Lorca", Sastrowardoyo menyerang moralitas Rendra yang ditudingnya membangun citra-citra yang memikat dalam baladanya dengan cara meniru citra-citra dalam puisi Lorca. Dalam pandangan Sastrowardoyo, kegiatan memproduksi karya sendiri berdasarkan apa yang disebutnya sebagai -alih bahasa atau sekurang-kurangnya saduran" dari karya orang lain adalah pelanggaran kode etik berat bagi seorang pengarang, semacam tindakan kriminal yang layak diganjar hukuman moral:

"Pokok yang dibicarakan di dalam sajak atau roman dapat saja bersifat umum dan dapat terjadi di mana saja, seperti perkosaan, pergolakan nafsu birahi, dan perkelahian sehingga boleh dikatakan milik pengalaman manusiawi. [...] Akan tetapi, pengolahan tema itu, di dalam penanggapan citra serta perwujudannya di dalam kesatuan bentuk karya adalah segi subjektif yang menjadi milik perseorangan pengarang, yang tidak boleh diambil-alih oleh pengarang lain tanpa menanggung akibatnya, yakni merendahkan nilai karya sendiri. Rendra telah rela merendahkan martabat ciptaan baladanya dengan meniru berbagai segi subjektif itu pada balada-balada penyair Spanyol, Federico Garcia Lorca (1899-1936)".

Berikut ini sebagian bukti yang diajukan Sastrowardoyo untuk "mengadili" moralitas Rendra dalam kasus “pencurian” balada Lorca: 
Jurnal Poetika Vol. I No. 2, Desember 2013

\begin{tabular}{|c|c|}
\hline BALADA LORCA & BALADA RENDRA \\
\hline $\begin{array}{l}\text { Her breasts of hard tin } \\
\text { They have skulls of } \\
\text { lead } \\
\text { The fig-tree rubs its air } \\
\text { with the sandpaper of } \\
\text { its } \\
\text { leaves }\end{array}$ & $\begin{array}{l}\text { Tersisa jantung dan bati } \\
\text { dari timah } \\
\text { Gagak-gagak dilekati } \\
\text { timah pada mata- } \\
\text { matanya } \\
\text { Bulan berkbianat } \\
\text { gosokgosokkan } \\
\text { tububnya di } \\
\text { pucuk-pucuke ara }\end{array}$ \\
\hline $\begin{array}{l}\text { The child signs } \\
\text { in the womb } \\
\text { of startled } \\
\text { Annunciacion } \\
\text { The full wind left in the } \\
\text { mount a strange taste } \\
\text { of gall of mint, and } \\
\text { sweet-basil } \\
\text { Green, green, I love } \\
\text { you } \\
\text { green, Green wind. } \\
\text { Green Branches. } \\
\text { The } \\
\text { ship upon the sea } \\
\text { and the } \\
\text { horse on the } \\
\text { mountain. } \\
\text { With the shadow at } \\
\text { her } \\
\text { waist she dreams on } \\
\text { her } \\
\text { balcony, green flesh, } \\
\text { green hair, and eyes } \\
\text { of } \\
\text { cold silver } \\
\text { Silence of lime and } \\
\text { myrtle; ah, what a } \\
\text { lemon, lemon of the } \\
\text { lemon-girl } \\
\text { His body laden with } \\
\text { lilies and a } \\
\text { pomegranate } \\
\text { on his brow }\end{array}$ & $\begin{array}{l}\text { Bulan jingga, telaga } \\
\text { kepundan jingga/ } \\
\text { rantingranting } \\
\text { pokok ara/ } \\
\text { terbencana darahku } \\
\text { segala } \\
\text { jingga } \\
\text { Bulan limau } \\
\text { O kuntum-kuntum } \\
\text { delima } \\
\text { ditebas belati } \\
\text { Mama, betapa tegak } \\
\text { ia./Buah asam gugur di } \\
\text { jalan/ia pungut dengan } \\
\text { tangan -/Oi! Betapa } \\
\text { disuka } \\
\text { kecutnya! }\end{array}$ \\
\hline
\end{tabular}

Half-way on the journey he picked round lemons, throwing them into the water until be turned it to gold; you weep drops of lemon, sour with waiting and sour to the mouth

When Soledad

Montoya

descends the dark mountain... Her

breasts

like smoky anvis, wail around songs; Down below the river sings: flounce of sky and leaves

Melihat bukti-bukti yang disodorkan Sastrowardoyo, andaikata memang benar Ballada Orang-Orang Tercinta ditulis berdasarkan balada Lorca, tampaknya Rendra hanya melakukan "apropriasi". Dalam seni apropriasi, seniman berkarya dengan mengacu pada karya orang lain yang sudah ada, biasanya secara ironis. Inilah praktek kreatif yang sah dan lumrah serta sudah lama berlangsung dan kini makin signifikan, terutama di lapangan seni rupa (bidang seni yang pernah digeluti Sastrowardoyo dan sering dirujuk dalam esai-esainya), lebih khususnya lagi seni rupa kontemporer/pascamodernis. Karya seni apropriasi adalah milik sah seniman pelaku apropriasi, bukan lagi milik seniman pencipta karya orisinil yang diapropriasi. Dalam kasus Rendra, barangkali masalahnya "hasil apropriasi" itu tidak ironis dan tidak secara jelas menunjuk sumbernya, sehingga terkesan seperti "pencurian". Tapi kalau pun dianggap sebagai kasus -pencurian", balada Rendra jelas bukan karya inferior. Sastrowardoyo sendiri mengakui: "Pada waktu kumpulan balada itu terbit, saya pun turut terpesona membacanya".

Saya tidak tahu reaksi Rendra terhadap esai "Kerancuan Pribadi Rendra-Lorca". Yang saya tahu, tetap ada kemungkinan bahwa kemiripan balada Rendra dan balada Lorca adalah "ciptaan" Sastrowardoyo sendiri, produk 
utak-atik interpretasi sang kritikus. Bisa juga balada Rendra memang meniru balada Lorca, namun peniruan ini terjadi di luar kesengajaan/ kesadaran Rendra.

Dalam kuliah di Universitas Cambridge, Inggris, pada tahun 1990 (Eco,2002), Umberto Eco mengungkapkan betapa sering pembaca/ kritikus menemukan "sumber" penulisan novel Eco - berbagai "sumber" yang justru tidak diketahui oleh sang penulis novel itu sendiri! Contohnya, Helena Costiucovich, penerjemah The Name of the Rose ke dalam bahasa Rusia, menulis esai bahwa novel terkenal Eco tersebut mirip novel La rose de Bratislava karya Emile Henroit, yang terbit lebih dulu daripada novel Eco. Judul novel Eco dan novel Henroit sama-sama mengandung kata "mawar", dan sama-sama pula menceritakan perburuan naskah misterius dan berakhir dengan kebakaran di perpustakaan. Kisah dalam novel Henroit berlangsung di Praha, kota yang juga disebut pada permulaan novel Eco. Salah satu pustakawan rekaan Eco bernama Berengar, dan dalam karya Henroit ada pustakawan bernama Berngard Marre. Kata Eco: "Percuma saja mengatakan bahwa, selaku pengarang empiris, saya tidak pernah membaca novel Henroit dan tidak pernah tahu ada novel itu". Seandainya ditulis oleh Sastrowardoyo, mungkin esai Costiucovich akan berjudul "Kerancuan Pribadi Eco- Henroit".

Contoh kasus lain, dalam The Name of The Rose, diceritakan tentang naskah misterius yang berisi jilid kedua yang hilang dari kitab Poetics karya Aristoteles, halaman-halamannya diolesi racun, beberapa halamannya lengket di dekat sudut atas dan sepanjang bagian atas kertas. Buku ini imajiner, rekaan Eco belaka. Tapi pada suatu hari, bertahun-tahun setelah menulis The Name of The Rose, Eco tak sengaja menemukan buku Poetics Aristoteles edisi tahun 1587, yang kondisinya nyaris sama dengan buku imajiner dalam novelnya, terselip dalam koleksi buku tua di perpustakaannya. Padahal, sebelumnya Eco sama sekali sudah lupa memiliki buku ini, yang puluhan tahun silam dibelinya dan digeletakkannya begitu saja. "Dengan semacam kamera batin, saya telah memotret halamanhalaman buku ini, dan selama berpuluh-puluh tahun, gambaran lembar- lembar beracun ini tersimpan di lubuk terdalam jiwa saya, sampai saatnya muncul kembali (entah karena alasan apa), dan saya percaya telah menciptakannya", kata Eco. Bercermin pada anekdot Eco ini, bukan mustahil Rendra pernah membaca dan dipesona balada Lorca, dan bacaan ini terekam di bawah-sadarnya, lalu di kemudian hari menyeruak kembali sebagai "ilham” yang menuntun penulisan Ballada Orang-Orang Tercinta. Esai "Kerancuan Pribadi Rendra-Lorca" memberikan kesaksian terang-benderang tentang ideologi modernis Sastrowardoyo, yang menempatkan individualitas, kreativitas, jenialitas, dan terutama orisinalitas, di puncak kriteria penilaian seni. Betapa kuatnya ideologi ini merasuki sang kritikus terlihat dari upayanya yang nyaris obsesif untuk membongkar ketidakorisinalan balada Rendra, bahkan ketidakorisinalan pribadi Rendra. Tanpa merasa risi, Sastrowardoyo sampai- sampai mempersoalkan hal-hal minor yang sebetulnya tidak substansial dan bahkan tidak relevan diajukan sebagai bahan pertimbangan untuk menilai balada Rendra sebagai seni. Nama tokoh Atmo Karpo dalam balada Rendra dikatakan "terdengar asing bagi telinga orang Jawa", dan diasosiasikan dengan nama tokoh Antonito el Camborio dalam balada Lorca. Judul "Ballada Terbunuhnya Atmo Karpo" dipandangnya meniru judul "Muertede Antonito el Camborio" karya Lorca. Seruan "Lala! Nana! tembang malam dan duka cita?" dalam puisi "Ballada Gadisnya Jamil, Si Jagoan” juga dikatakan "amat asing bagi telinga Indonesia", serta mirip nyanyian kanak-kanak yang amat disukai Lorca, yang berbunyi: "A la nana, nana nana/ a la nanita de aquel/ que llove el caballo al agua/y lo dejo sin beber..." Paling parah, sang kritikus sempat-sempatnya menulis catatan kaki:

"Saya tidak dapat menghindarkan dugaan bahwa singkatan nama Wilibrordus Surendra menjadi W.S. Rendra (singkatan nama yang ganjil di dalam bahasa Jawa) tidak lain adalah hasil identifikasi dirinya 
Jurnal Poetika Vol. I No. 2, Desember 2013

dengan nama F.G. Lorca”.

Rupanya, bagi Sastrowardoyo, apa pun layak dipakai untuk menelanjangi ketidakorisinalan Rendra-karya maupun pribadinya. Praktek penelanjangan "total" semacam ini tentu sulit diterima sebagai dasar penilaian mutu seni, tetapi sungguh efektif sebagai metode penilaian mutu moralitas seniman. Bahwa esai "Kerancuan Pribadi Rendra-Lorca" bukanlah kritik estetika, melainkan kritik etika, tercermin pula pada keengganan Sastrowardoyo untuk menanggapi puisi Rendra sesudah Ballada Orang-Orang Tercinta-karena khawatir tertipu lagi oleh kemolekan tarian Sang Burung Merak:

"Alasan lain kekhawatiran saya adalah perubahan tanggapan yang mungkin akan saya alami dalam mempertimbangkan sajak- sajak Rendra yang baru, termasuk "Nyanyian Angsa" dan "Khotbah" dari kumpulan Blues untuk Bonnie, yang telah menaikkan gelombang perhatian terhadap penyairnya pada saat terbitnya. Pada diri saya, pertimbangan sajak-sajak Rendra memerlukan jarak tinjauan yang lebih jauh dari karya-karya pengarang lain karena jangan-jangan pesona pertama yang diterbitkan penyair yang sudah telanjur populer ini tidak menjanjikan nilai yang kita sangka semula. Hal itu telah terjadi di dalam diri saya ketika menghadapi Ballada Orang- Orang Tercinta. Setelah lewat beberapa waktu saja, pada penglihatan saya pesona itu telah menjadi pudar, sedangkan di dalam kerja sastra, yang kita tuju terutama adalah nilai-nilai yang kekal".

\section{Epilog}

Teeuw (1984) memuji Subagio Sastrowardoyo sebagai salah seorang kritikus sastra Indonesia yang menghasilkan analisis struktur yang bagus dalam sejumlah kajian sastranya. Ia tidak menyebut kajian mana saja yang dianggapnya berhasil itu. Tetapi salah satunya tentu kajian Sastrowardoyo tentang puisi Sitor Situmorang dalam SPdS. Esai tersebut diajukan Teeuw "sebagai contoh dan pembicaraan yang sangat tepat" tentang ikhtiar mencari kebulatan makna yang tersembunyi dan sukar dipahami dalam puisi modern-dalam kasus ini puisi Situmorang.

Dari empat surat-upaya dalam SPdS, esai "Manusia Terasing di Balik Simbolisme Sitor" memang paling banyak memberikan perhatian pada aspek bentuk karya. Tetapi, secara keseluruhan, SPdS ditulis dengan orientasi ekspresif yang mengutamakan interpretasi tentang dunia batin, kejiwaan atau "sosok pribadi" pengarang sebagaimana yang terbayang pada isi karyanya. Penekanan kuat pada isi, disertai kuatnya paham romantik dan modernis yang menempatkan seniman di pusat penciptaan seni, telah mendorong Sastrowardoyo untuk merancukan penilaian mutu karya dan penilaian kualitas pribadi pengarang, mengaburkan perbedaan antara kritik seni dan kritik moralitas, mencampuradukkan persoalan estetika dan perkara etika. Ketajaman, kecermatan dan ketekunan analisis Sastrowardoyo seringkali diredupkan atau dipiuhkan oleh hasrat melakukan semacam "inkuisisi suci" terhadap pengarang. Di satu sisi, hal ini dapat dipandang sebagai kelemahan. Namun di sisi lain, juga menjadi kekuatan yang memberikan nada polemis khas pada SPdS, sehingga esaiesai di dalamnya menjadi lebih "seksi" dan "abadi", lebih dikenang pembaca daripada esai-esai Sastrowardoyo dalam buku lain, atau bahkan dibanding kebanyakan telaah sastra oleh kritikus sastra Indonesia lainnya.

Meski masih harus dibuktikan dengan analisis terhadap puisi Sastrowardoyo, kritisisme tentang puisi dalam SPdS boleh jadi merefleksikan pendirian dan ideal Sastrowardoyo selaku penyair dalam memandang puisi dan kepenyairan. Kita tentu boleh berspekulasi bahwa Sastrowardoyo selaku penyair mencitacitakan puisi yang berpijak di bumi sendiri (lawan dari Chairil Anwar yang berjiwa Eropa), orisinal dan jujur dan dalam (lawan dari Rendra yang tidak orisinal dan berpura-pura dan dangkal), berbobot filosofis dan didasari kesungguhan pengalaman (seperti Sitor Situmorang, minus sikapnya yang dibuat-buat), serta lembut dan kaya warna (seperti Toto Sudarto Bachtiar, minus keluguannya). Keberanian melontarkan kritik, 
Jurnal Poetika Vol. I No. 2, Desember 2013

dengan argumen yang kaya dan berwawasan luas, terhadap karya dan sosok penyair populer yang telah nyaris menjadi "mitos" dalam sejarah sastra modern Indonesia adalah poin berharga yang ikut mengerek kewibawaan dan ketokohan Sastrowardoyo sebagai salah satu kritikus sastra Indonesia terpenting.

Dalam SHBdK, Sastrowardoyo bergeser menjauhi kutub ekspresif dan mendekati kutub struktural, meski tidak pernah kehilangan minat kepada-sosok pribadi" pengarang. Hasilnya adalah serangkaian telaah sastra yang terasa lebih obyektif, lebih berjarak, lebih dingin, tapi sekaligus kurang memikat dibanding SPdS. Keterlibatan personal sang kritikus dengan obyek kajiannya dalam $S H B d K$ tidak sekuat dalam SPdS. Patut diduga, hal ini karena SPdS membicarakan puisi, genre sastra yang digeluti Sastrowardoyo sendiri dengan intens sebagai penyair, sementara $S H B d K$ membahas roman, terlebih lagi roman Hindia-Belanda. Namun demikian, $S H B d K$ dalam arti tertentu lebih penting kedudukannya daripada SPdS, mengingat langkanya kajian dan kurangnya pengetahuan kita tentang khazanah sastra Hindia-Belanda yang, betapa pun, telah ikut membentuk kesadaran historis tentang negeri dan bangsa Indonesia.

Dengan segala kelebihan dan kekurangannya, Subagio Sastrowardoyo adalah sosok kritikus sastra yang bukan saja cerdas dan tekun, tapi juga berani dan bertanggung-jawab. Ia telaten mengkaji, piawai membedah, dan punya nyali menilai. Kualitas yang selamanya langka di dunia sastra kita.

\section{Daftar Pustaka}

Korrie Layun Rampan. 2000 Leksikon Susastra Indonesia. Jakarta: Balai Pustaka.

Pamusuk Eneste. 2001. Buku Pintar Sastra Indonesia. Jakarta: Kompas.

Yudiono K.S, 2009. Pengkajian Kritik Sastra Indonesia. Jakarta: Grasindo.

Teeuw, A. 1984. Sastra dan Ilmu Sastra: Pengantar Teori Sastra. Jakarta: Pustaka Jaya.

Eco, Umberto. 2002. Interpretation and Overinterpretation. Cambridge: Cambridge University Press,

Susan Sontag, 1990. Against Interpretation. New York: Dobleday 